\title{
Diary
}

\section{2-23 June}

Collaborative e-Learning: Sustaining communities, supporting processes Cambridge, UK

Information: Universities' Collaboration in eLearning (UCeL), University of Cambridge, 16 Mill Lane, Cambridge CB2 1SB, UK Tel: +44 (0)1223765363

Fax: +44 (0)1223 765505

Email: info@ucel.ac.uk

\section{4-5 July}

10th International Computer Assisted

Assessment Conference

Loughborough, UK

Information: Sonya Medlock, Conference

Secretary, Professional Development,

Loughborough University,

Leicestershire LE11 3TU, UK

Tel: +44(0)1509223736

http://www.caaconference.com/

\section{4-6 July}

Pacific Second Language Research Forum 2006 Part of the LINQ 2006 series of linguistic events at the University of Queensland Brisbane, Australia Information: PacSLRF 2006, EMSAH, Michie Level 4 University of Queensland Brisbane QLD 4072, Australia

Email: m.haugh@gu.edu.au

\section{5-7 July}

DIVERSE 2006

Glasgow, UK

Information: DIVERSE Conference, eLISU, Glasgow Caledonian University, 6 Rose Street, Glasgow G3 6RB, UK

Tel: +44 (0)1412731330

Email: diverse@gcal.ac.uk

\section{6-8 July}

Annual Conference of the Applied Linguistics Association of Australia
Brisbane, Australia

Part of the LINQ 2006 series of linguistic events at the University of Queensland

\section{4-16 July}

IADIS Mobile Learning 2006

Dublin, Ireland

Information:ml-sec@iadis.org

\section{9-21 July}

5th International Conference on Web-based Learning (ICWL2006)

Penang, Malaysia

\section{0-22 August}

Didascalia 12th International CALL Research Conference: How are we doing? CALL \& Monitoring the Learner Antwerb, Belgium Information: Didascalia, Universiteit Antwerpen, Campus Drie Eiken, Universiteitsplein 1, D 0.10, 2610 Wilrijk, Belgium Tel: +32(0)3 8202969 Fax: +32 (0)3 8202986 Email:didascalia@ua.ac.be

\section{4-7 September}

EUROCALL 2006

Granada, Spain

Information: Dr. Tony Harris, English

Department, Facultad de Filosofía y Letras, Campus Universitario de Cartuja, s/n Granada, 18071, Spain

Web: http://www.eurocall-languages.org/

\section{5-7 September}

ALT-C 2006

Edinburgh, UK

Information: ALT Administration, Oxford

Brookes University, Headington,

Oxford OX3 0BP, UK

Tel: $+44(0) 1865484125$

Fax: +44 (0)1865 484165

Email: alt@brookes.ac.uk

Please note: an up-to-date and expanded version of this Diary may be found at http://www.eurocall-languages.org/resources/calendar.htm 


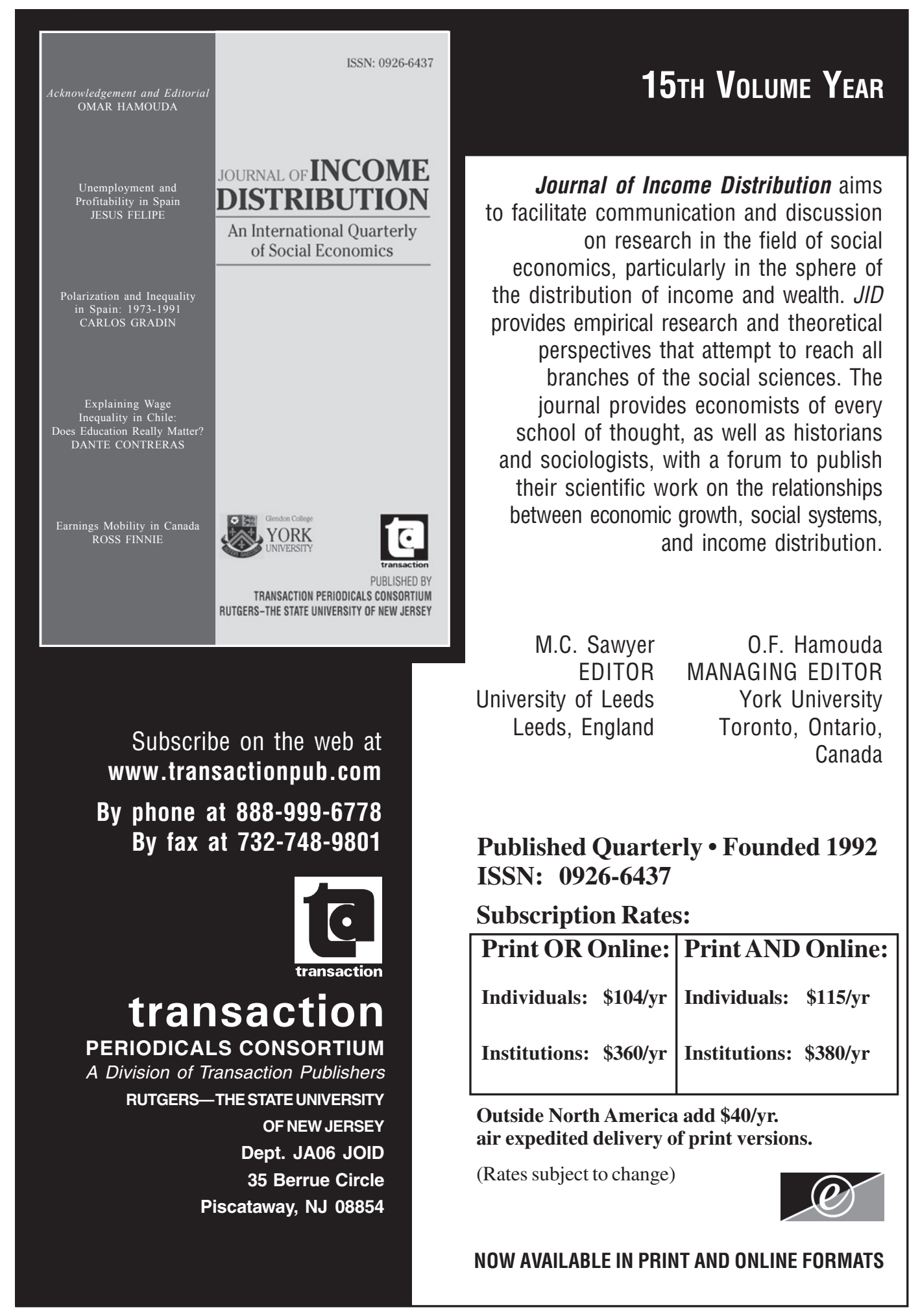




\section{CAMBRIDGE}
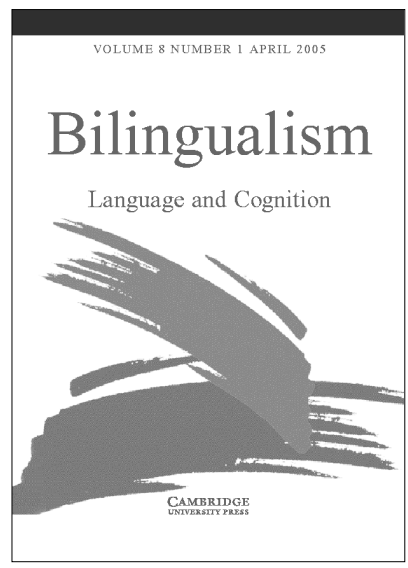

online Bilingualism: Language and Cognition is available online at: www.journals.cambridge.org/jid_BIL

To subscribe contact Customer Services

in Cambridge:

Phone +44 (0)1223 326070

Fax +44 (0)1223 325150

Email journals@cambridge.org

in New York:

Phone (845) 3537500

Fax (845) 3534141

Email

journals_subscriptions@cup.org

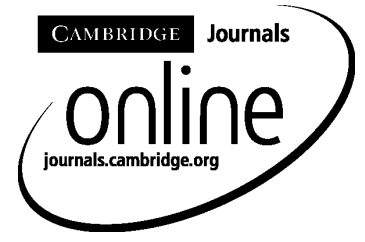

\section{Bilingualism: Language and Cognition}

\section{Editors}

David W. Green, University College London, UK Ping Li, University of Richmond, USA

Juergen M. Meisel, Universität Hamburg, Germany Carmen Silva-Corvalán, University of Southern California, USA

Bilingualism is an international peer-reviewed journal focusing on bilingualism from a cognitive science perspective. The aims of the journal are to promote research on the bilingual person and to encourage debate in the field. Areas covered include: bilingual language competence, perception and production, bilingual language acquisition in children and adults, neurolinguistics of bilingualism in normal and brain-damaged subjects, and non-linguistic cognitive processes in bilinguals.

Price information is available at: www.journals.cambridge.org/jid_BIL

Free email alerts!

Keep up-to-date with new material sign up at www.journals.cambridge.org/register 


\section{CAMBridge}

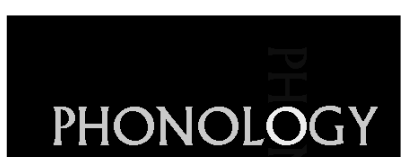

\section{Phonology}

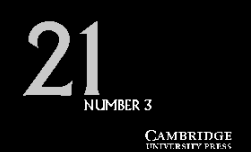

Phonology
is available online at:

www.journals.cambridge.org/jid_PHO

To subscribe contact Customer Services

\section{in Cambridge:}

Phone +44 (0)1223 326070

Fax +44 (0)1223 325150

Email journals@cambridge.org

in New York:

Phone (845) 3537500

Fax (845) 3534141

Email

journals_subscriptions@cup.org

\section{Editors}

Colin J. Ewen, University of Leiden, The Netherlands Ellen M. Kaisse, University of Washington, USA

Phonology, published three times a year, is the only journal devoted exclusively to the discipline. It reflects both theoretical and empirical interests, and provides a unique forum for the productive interchange of ideas among phonologists and those working in related disciplines. The journal carries research articles, as well as book reviews and shorter pieces on topics of current controversy within phonology.

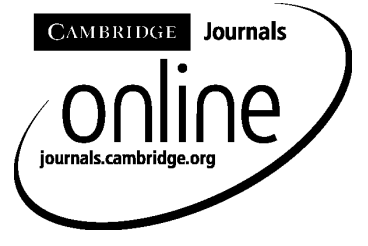

Price information is available at: www.journals.cambridge.org/jid_PHO

Free email alerts!

Keep up-to-date with new material sign up at www.journals.cambridge.org/register 
CAMbridge

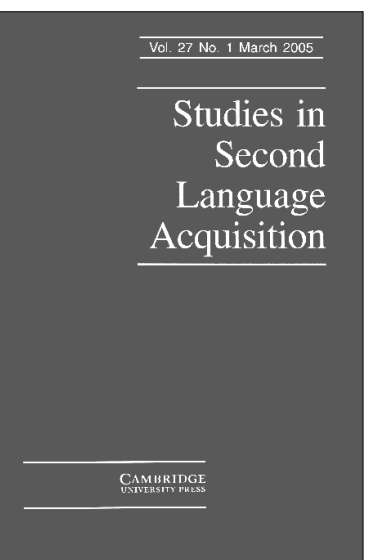

Studies in

Second

Language

Acquisition

online) Studies in Second Language Acquisition

is available online at:

www.journals.cambridge.org/jid_SLA

\section{Editor}

Albert Valdman, Indiana University, USA

Studies in Second Language Acquisition is a refereed journal of international scope devoted to the scientific discussion of issues in second and foreign language acquisition of any language. Each volume contains four issues, one of which is generally devoted to a current topic in the field. The other three issues contain articles dealing with theoretical topics, some of which have broad pedagogical implications, and reports of quantitative and qualitative empirical research.

in New York:

Phone (845) 3537500

Fax (845) 3534141

Email

journals_subscriptions@cup.org

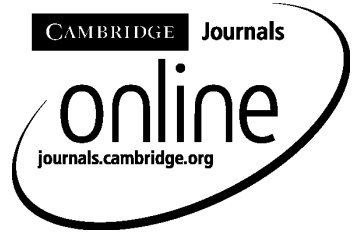

Price information is available at: www.journals.cambridge.org/jid_SLA

Free email alerts!

Keep up-to-date with new material sign up at www.journals.cambridge.org/register 